\title{
Jomlo sampai Halal: Refleksi Sosiologis Budaya Generasi Milenial pada Mahasiswa Jomlo di IAIN Pontianak
}

\author{
Khairunnisyah, ${ }^{1}$ Zaenuddin Hudi Prasojo ${ }^{2}$ \\ ${ }^{1,2}$ Institut Agama Islam Negeri Pontianak - Indonesia
}

\begin{abstract}
The article is based on the fact that "jomlo" or being single has become a new trend as a sociological phenomenon and the product of the practice of hijrah within the life of Muslim youth, especially Indonesian Muslim students. The concept of dating for those who practice the "men-jomlo" is very important in this work today. They, in fact, have unintentionally started to create a new culture of being "jomlo" although they are not being involved in a community designed for those practicing "jomlo". This work attempts to provide analytical discussions on the concept of dating according to the students who practice the "jomlo", what they mean by "jomlo" to halal, and their motivation to practice the "jomlo". With the support of qualitative data, the work provides important findings on the practice of "jomlo" by the students of IAIN Pontianak. First, generally, the students agree that dating tends to lead to negative than positive attitudes so that they decide to choose being single or "jomlo" until they get married for halal relationship. Second, they believe that Islam does not have a concept of dating as understood by the youth today in the modern world and there is no Islamic dating. Third, religious conciseness has become the main element to motivate them so that they tend to rather choose to practice "jomlo" until they find their halal wife as they say "jomlo sampai halal."
\end{abstract}

Artikel ini didasarkan pada kenyataan maraknya tren men-jomlo sebagai sebuah fenomena sosiologis dan produk perilaku hijrah di kalangan generasi muda Islam di kalangan mahasiswa Islam di Indonesia. Konsep pacaran dalam perspektif mahasiswa yang memilih untuk tidak berpacaran menjadi sangat penting untuk dikaji saat ini. Secara tidak disengaja mereka telah membentuk sebuah budaya men-jomlo meskipun mereka tidak sedang berada dalam sebuah komunitas yang sengaja dibentuk untuk itu. Tulisan ini mendiskusikan konsep pacaran menurut mahasiswa yang memilih untuk jomlo (tidak berpacaran), konsep jomlo sampai halal, dan motivasi mahasiswa untuk tidak berpacaran. Dengan dukungan data-data kualitatif, tulisan ini menyuguhkan temuan-temuan penting tentang perilaku men-jomlo mahasiswa IAIN Pontianak. Pertama, secara umum mahasiswa IAIN Pontianak sepakat menyatakan bahwa pacaran yang lebih banyak mendatangkan hal-hal yang negatif daripada yang positif sehingga mereka memilih men-jomlo. Kedua, mereka meyakini bahwa tidak ada konsep pacaran dalam Islam dan tidak ada pacaran yang Islami. Ketiga, kesadaran beragama menjadi motivasi utama sehingga mahasiswa lebih memilih untuk tidak berpacaran atau jomlo sambil menanti pasangan yang sah atau dengan kata lain "jomlo sampai halal."

Keywords: dating; jomlo; halal; student

Korespondensi Penulis: Zaenuddin Hudi Prasojo (zaestain@yahoo.com). Instutut Agama Islam Negeri Pontianak. Jl. Letjend. Suprapto No. 19 Pontianak, Indonesia 78122. 


\section{Pendahuluan}

Terjadi pergeseran eksistensi fenomena berpacaran di kalangan generasi muda saat ini yang salah satunya disebabkan oleh maraknya tren jomlo. Berbagai macam motivasi, baik dalam bentuk tulisan seperti buku-buku motivasi Islami maupun dalam bentuk akun-akun sosial media hijrah jomlo, seminar muslimah, dan segala bentuk kegiatan lainnya, dengan sengaja dibangun sehingga tren jomlo berhasil menyaingi eksistensi tren untuk berpacaran khususnya pada generasi muda Islam saat ini. Menjomlo sampai halal yang menjadi pembahasan dalam tulisan ini menjadi salah satu produk perilaku dari maraknya perilaku hijrah di kalangan generasi muda Islam saat ini. Sementara itu perubahan budaya terus berubah seiring berjalannya waktu. Banyak faktor yang dapat mempengaruhi perubahan tren, baik dari aspek gagasan, ide, dan perilaku. Perubahan tidak hanya terjadi pada persoalan tingkah laku yang tampak, tetapi juga pada aspek yang cenderung tidak tampak seperti pola berpikir, sudut pandang dan relijiusitas seseorang. Mudji Sutrisno dan Hendar Putranto (2005) menjelaskan bahwa jika dikatakan bahwa tidak ada yang tetap di dunia ini mungkin yang tetap hanyalah perubahan itu sendiri. Seiring konteks zaman yang berubah, manusia dengan alam pikir dan rasa, karsa dan cipta, mengalami perubahan yang mempengaruhi budayanya.

Demikian pula dalam beragama, manusia cenderung mengikuti perubahan tren yang mengikuti praktek kehidupan beragama dalam keseharianya. Perubahan dapat pula dimaksudkan untuk memperbaiki diri, memahami dan mengamalkan setiap ajaran yang ia yakini kebenarannya, sehingga perubahan perilaku, perubahan cara berpakaian, gaya hidup dan perubahan cara pandang yang ekstrem serta mendominasi pada diri seseorang tidak lagi menjadi sesuatu yang tabu. Dalam hal mencari pasangan hidup, misalnya, terdapat banyak faktor yang menjadi pertimbangan sehingga mendorong seseorang untuk serius melepaskan status berpacarannya serta memotivasi seseorang untuk berani keluar dari zona nyaman berpacaran selain dari tuntutan agama. Selain itu, pandangan masyarakat, keluarga, pemahaman atau cara pandang seseorang terhadap perilaku pacaran atau status pacaran juga dapat menjadi faktor yang mendorong seseorang untuk istiqāmah menjalani hidupnya dengan memilih untuk berstatus jomlo sampai waktu menikah. Sebenarnya di dunia Barat tidak terlalu dibahas mengenai pacaran ini, walaupun masyarakat Barat tentu memilikinya. Hanya saja konsepnya pasti berbeda. Kajian ini dapat menjadi salah satu bagian dari perbandingan nilai yang berkembang di dunia Timur dan budaya Barat (Panaemalae dan Prasojo 2016).

Saat ini perilaku men-jomlo sampai halal menjadi tren budaya pada generasi muda Muslim khususnya, sebagai produk dari adanya perubahan. Koentjaraningrat (2009) mengatakan bahwa hampir seluruh tindakan manusia adalah kebudayaan karena kebudayaan adalah keseluruhan sistem gagasan, tindakan dan hasil karya manusia dalam kehidupan masyarakat yang dijadikan milik diri manusia dengan belajar. Sangat sedikit perilaku manusia yang 
tidak perlu dibiasakan dengan belajar yang memang telah dibawa sejak lahir. Tulisan ini dimaksudkan untuk mengkaji konsep pacaran pada generasi muda muslim dan muslimah pada mahasiswa IAIN Pontianak yang memilih untuk jomlo sampai halal. Generasi muda muslim dan muslimah yang dimaksud dalam hal ini adalah anak-anak muda yang beragama Islam, yang berusia antara 19 tahun sampai dengan 23 tahun dan merupakan mahasiswa IAIN Pontianak yang memilih untuk berstatus jomlo. Adapun beberapa hal yang menarik untuk diperhatikan meliputi bagaimana konsep pacaran menurut mahasiswa yang memilih untuk jomlo, bagaimana konsep jomlo sampai halal dan apa yang memotivasi mahasiwa saat ini memilih untuk men-jomlo serta bagaimana realitanya dalam kehidupan sosial masyarakat.

Beberapa tulisan yang terkait tentang jomlo sampai halal dapat disebutkan di sini, misalnya, buku-buku motivasi muslimah karya Ahmad Rifa'i Rifan tentang The Perfect Muslimah, Ya Allah Izinkan Aku Pacaran, dan Jomblo Sebelum Menikah. Kemudian, ada juga buku karya M. Amin yang berjudul From Jomlo to Nikah, buku karya Retno D. N. yang berjudul Pakai Jilbab, Kok, Pacaran? dan beberapa tulisan lagi yang berupa buku-buku motivasi lainnya yang membahas tentang pacaran sampai halal dan menanti jodoh dengan memantaskan diri. Dengan mengamati gejala-gejala sosial tentang perubahan budaya di kalangan generasi muda muslim dan muslimah di kalangan mahasiswa IAIN Pontianak, tulisan ini juga didukung oleh analisis data kualitatif deskriptif. Penelitian ini dilakukan dengan memanfaatkan data berupa postingan-postingan di akun sosial media seperti Instagram dan WhatsApp. Kemudian penulis juga memanfaatkan data dari hasil observasi dan wawancara dengan mahasiswa yang berstatus jomlo. Setelah itu data tersebut dikumpulkan dan dianalisis secara deskriptif kualitatif dengan menghubungkannya pada konteks yang disesuaikan dengan isu perubahan sosial generasi melinial.

\section{Jomlo sampai Halal dalam Tinjauan Sosial dan Spiritual}

Kata "jomlo" (tanpa huruf "b") dalam Kamus Besar Bahasa Indonesia (KBBI) berarti gadis tua yang belum menikah. Seiring perkembangan zaman, jomlo mengalami perluasan makna, sehingga tidak lagi disebutkan untuk gadis yang belum punya pasangan, melainkan laki-laki juga bisa disebut jomlo. Pada masa remaja, banyak remaja yang memiliki pandangan bahwa masa remaja adalah masa berpacaran. Sehingga, yang tidak berpacaran atau jomlo justru dianggap sebagai remaja yang kuno, kolot, tidak mengikuti perubahan jaman dan dianggap kuper atau kurang pergaulan (Faiza 2018). Namun, perlu diperhatikan beberapa hal mengenai pacaran dalam tinjauan sosial dan spiritual. Menurut Iis Ardhianita dan Budi Andayani (2005) ada 2 pandangan dalam Islam terkait pacaran. Pandangan pertama, yang lebih populer di kalangan aktivis dakwah, menganggap pacaran sebagai suatu hubungan yang dilarang dalam Islam. Sedangkan, pandangan kedua melihat pacaran dapat dijalani selama dilakukan secara Islami. Menurut Pujiati, Soesanto, dan Wahyuni (2013) pacaran ada 2 jenis yaitu pacaran sehat 
dan pacaran tidak sehat. Pacaran sehat meliputi pacaran sehat secara fisik, psikis dan sosial. Pacaran tidak sehat meliputi kissing, necking, petting, dan intercourse.

Pandangan yang melarang pacaran didasarkan pada pemahaman bahwa cinta atau ketertarikan pada lawan jenis adalah hal yang alamiah, namun Islam mengatur cara yang baik untuk menyalurkannya yaitu melalui sistem pernikahan. Islam tidak mengenal cara pertunangan, pacaran ataupun hubungan pranikah lainnya. Islam membedakan antara cinta dan seks sebagai nafsu. Cinta adalah mawaddah dan rahmah, sedangkan nafsu seks sebagai naluri adalah nafsu syahwat. Keduanya di dalam Islam hanya bersatu dalam perkawinan, karena cinta yang bersemi setelah perkawinan adalah cinta yang dijamin Allah. Menurut Abdul Aziz dan Faiz Aminuddin (2014) dalam hukum Islam tidak ada bukti cinta yang lebih meyakinkan selain pernikahan, karena cinta sejati akan diwujudkan dalam pernikahan sebagai tujuan akhir sekalipun saat ini tren pernikahan berujung pada perceraian. Sementara pandangan yang memperbolehkan pacaran atas dasar Islami diawali dengan konsep pacaran dibenak remaja yang dikaitkan dengan kebutuhan kasih sayang dari seorang teman akrab. Pacaran juga dikaitkan dengan hubungan dekat dalam berkomunikasi dengan lawan jenis sehingga dapat membangun kedekatan emosi dan proses pendewasaan kepribadian untuk melangkah ke tahapan selanjutnya yaitu pernikahan. Menurut Aziz dan Aminuddin (2014) Islam tidak melarang seseorang untuk mencintai atau dicintai siapa saja, selama cinta yang bersemayam di dalam hati adalah cinta yang suci, namun sering kali cinta itu berpindah dari dunia rasa ke dunia nyata dan sering kali ternoda syahwat dan nafsu birahi. Pada prinsipnya Islam tidak melarang rasa cinta. Islam melarang ketika cinta tersebut diekspresikan dalam hubungan fisik sehingga ketika mendengar kata pacaran seharusnya tidak melulu mebayangkan bahwa pacaran yang dimaksud selalu identik dengan perilakuperilaku seksual pra-nikah.

Menurut Aziz dan Aminuddin (2014) Islam sebenarnya sangat respek terhadap usaha seseorang untuk lebih mengenal calon yang akan dinikahinya, sebagaimana ketatnya ramburambu yang digariskan oleh Islam seperti harus benar-benar mengenal kondisi fisik, karakter, kepribadian, akhlak dan latar belakang orang yang dicintai, dengan tujuan supaya tidak mendapatkan pasangan yang salah dari sisi akidah, akhlak dan nasab, sehingga akan terhindar dari kekecewaan di kemudian hari. Jadi, menurut Aziz dan Aminuddin (2014) pacaran yang dikehendaki Islam adalah selama pacaran atau rasa cinta tidak diwujudkan dalam hubungan fisik dan biologis. Agar pacaran benar-benar sesuai dengan tuntutan Islam, perlu memperhatikan beberapa hal yaitu bahwa pacaran dilakukan sebagai batu loncatan ke arah yang lebih serius yaitu menikah, pacaran dimaksudkan sebagai sarana mengenal karakter pasangan dan pacaran dilakukan sebagai pemberi motivasi diri, memperbaiki diri karena jodoh. Ketiga hal tersebut dimaksudkan agar tidak mendapatkan pasangan yang salah, baik dari sisi agama, akidah, akhlak, dan nasab, sehingga terlepas dari penyesalan di kemudian hari. 
Namun, belakangan seiring dengan perkembangan teknologi dan pengetahuan (dari media massa), telah terjadi pula pergeseran konsep pacaran menjadi menyimpang dan lebih mengarah kepada perilaku seksual yang dikaitkan dengan keintiman hubungan dalam bentuk hubungan seks pra nikah. Mungkin ada beberapa faktor yang menyebabkan terjadinya pergeseran konsep pacaran di kalangan remaja, perilaku yang seharusnya dianggap sangat negatif tersebut justru hari ini dianggap hal yang biasa di kalangan masyarakat tertentu.

Dalam hal ini pemahaman seseorang terhadap agama menjadi sangat penting, untuk menanamkan nilai-nilai akhlak sehingga dapat membatasi perilaku yang negatif. Religiusitas berfungsi sebagai suatu sistem nilai yang memuat norma-norma tertentu yang menjadi kerangka acuan dalam bersikap dan bertingkah laku agar sejalan dengan keyakinan agama yang dianutnya. Namun, setelah dilakukan sebuah penelitian, terungkap bahwa tidak ada hubungan antara religiusitas yang tinggi dengan prilaku seks pranikah. Walaupun memiliki pemahaman yang tinggi tentang ajaran agamanya tidak dapat menjamin seseorang tidak melakukan hal-hal yang negatif (Firmiana, Prasetya, dan Imawati 2014). Menurut Ani Agustiyani Maslahah (2013) pada umumnya jika para remaja yang mengalami gejala disorganisasi sosial dalam keluarga maka norma dan nilai sosial menjadi kehilangan kekuatan untuk mengikat, sehingga kontrol sosial menjadi lemah dan memungkinkan terjadinya berbagai bentuk penyimpangan perilakunya. Hal inilah yang menjadi salah satu faktor terjadinya pergeseran konsep pacaran di kalangan remaja di mana nilai-nilai kebudayaan yang mengikat seseorang menjadi semakin hari semakin memudar. Remaja kehilangan nilai-nilai adatistiadat di dalam hidupnya sehingga dapat dengan mudahnya melakukan penyimpanganpenyimpangan dalam bentuk berhubungan seks tanpa melakukan pertimbangan mendalam.

Menurut Maslahah (2013) pengertian pacaran dalam era globalisasi informasi ini sudah sangat berbeda dengan pengertian pacaran 15 tahun yang lalu. Sejalan dengan hal itu Hurlock (dalam Setiawan dan Nurhidayah (2008) mengatakan bahwa perubahan konsep pacaran tersebut juga di bentuk oleh pola pikir kebanyakan remaja tidak ingin dianggap sebagai anak kecil tetapi akan lebih bangga bila dianggap sudah dewasa. Sehingga ada pula pandangan bahwa perilaku seksual dianggap sebagai simbol status kedewasaan. Selain itu, pacaran dipandang sebagai hal yang wajar oleh remaja dan bahkan mereka justru merasa malu jika jomlo. Bagi remaja, jomlo adalah kutukan yang harus dihilangkan. Namun di sisi lain, ada gerakan baru yang justru berlawanan dengan pemahaman yang berkembang di kalangan umum. Gerakan baru tersebut mengusung konsep baru mengenai konsep pacaran dan mengusung konsep jomlo sampai halal. Pergeseran konsep pacaran menyebabkan banyak sekali remaja-remaja muslim hari ini yang memilih untuk lajang atau jomlo daripada berstatus pacaran demi menghindari kemaksiatan. Transformasi konsep pacaran hari ini memberikan efek kepada para remaja muslim mengenai 
konsep jomlo pada abad millennial. Saat ini jomlo tidak lagi dianggap sebagai suatu status yang memalukan, justru sebaliknya jomlo menjadi status yang dianggap positif meskipun masih ada beberapa komunitas yang menganggap jomlo sebagai hal yang memalukan. Kesadaran seseorang tentang ajaran agamanya membuat konsep jomlo saat ini mengalami transformasi khususnya di kalangan remajaremaja muslim di Pontianak.

Pada generasi milenial, pergeseran konsep pacaran diiringi pula dengan pergeseran konsep jomlo. Eksistensi transformasi konsep jomlo di era milenial terlihat dengan maraknya remajaremaja muslim hari ini yang bangga dengan status jomlo. Budaya jomlo sampai halal juga terefleksi dengan maraknya berbagai kegiatan kajian-kajian muslimah yang membahas tentang jomlo sampai halal, tentang ta'aruf dan tentang nikah muda khususnya di kota Pontianak. Bahkan tidak hanya di kota Pontianak, di kota lainnya ada yang lebih kreatif dengan membentuk komunitas-komunitas jomlo sampai halal seperti Ikatan Jomlo Lucu dan Imut (Ijo Lumut), Ikatan Jomlo Terhormat (Ijo Tomat), dan Komunitas Pelajar Tanpa Pacaran (PTP) di kota Surabaya. Selain itu, ada pula orang-orang kreatif lainnya yang menklasifikasi jomlo secara syariah seperti jomlo fi sabilillah, jomlo wallahu a'alam, jomblo shaumaghadin, jomblo shirathal mustaqim, jomlo mukhlisin, jomlo nawaitu, jomlo mughaladhah, jomlo tahlil, jomlo summum bukmun, jomlo lailatul qadar dan lain sebagainya (ada sebanyak 31 klasifikasi jomlo berdasarkan filosofi-filosofi tentang jomlo pada abad milenial (Faiza 2018). Kesadaran beragama membentuk pola pikir seseorang ke arah yang lebih baik. Secara tidak langsung kesadaran beragama pada remaja membantu instansi pendidikan seperti sekolah dan perguruan tinggi dalam merealisasikan program-program akhlak mulia pada remaja, melalui materi-materi pendidikan agama Islam dan berimplikasi pula dalam membantu menekan angka kenakalan di usia remaja.

Institusi-institusi pendidikan saat ini memiliki kualitas dan fasilitas yang cukup memadai. Namun penekanan kepada pentingnya anak didik untuk hidup dengan nilai-nilai kebaikan, spiritual dan akhlakulkarimah seperti masih belum maksimal. Bahkan kondisi yang terjadi saat ini munjukkan bahwa pendidikan diarahkan untuk melahirkan individu-individu yang pragmatis yang bekerja meraih kesuksesan materi dan profesi sosial yang akan memakmurkan diri. Gelar dianggap sebagai tujuan utama (Syarif 2014). Seharusnya melalui penyelenggaraan pendidikan yang bernuansa akhlak mulia diharapkan dapat memberi arah kepada peserta didik setelah menerima berbagai ilmu pengetahuan dan dapat membina akhlak remaja sehingga mereka bisa menerapkan ilmu di tengah-tengah masyarakat dengan tetap berpatokan pada nilai-nilai kebenaran dan kebaikan (Nugraha 2015). Pendidikan di sekolah maupun di perguruan tinggi menjadi tumpuan utama bagi masyarakat (Su'dadah 2014). Dengan demikian materi-materi pendidikan agama Islam dikembangkan dalam keseharian sehingga peserta didik dapat menjadi taat pada agama dan negara. Ketaatan tersebut secara tidak langsung akan membentuk akhlak yang baik pada generasi-generasi muda, 
pikiran yang jernih untuk pembentukkan karakter bangsa, sehingga mereka dapat menentukan pilihan hidup yang baik pula untuk dirinya. Dengan demikian jomlo sampai halal dapat menjadi budaya di kalangan generasi muda, serta merupakan salah satu bentuk kepribadian generasi muslim dan muslimah dalam memandang bahaya pacaran dan maraknya seks bebas di Indonesia.

\section{Jomlo sampai Halal: Refleksi Sosiologis Budaya Mahasiswa Jomlo di IAIN Pontianak}

Jomlo sampai halal telah menjadi bagian penting di kalangan mahasiswa IAIN Pontianak saat ini. Sebagian mahasiswa-mahasiswi IAIN Pontianak memiliki pandangan yang sama terhadap konsep pacaran, perilaku pacaran, bahaya pacaran dan segala hal yang dianggap lebih banyak negatif daripada positif dari berpacaran. Hal ini juga memberikan efek kepada pemahaman dan perilaku mahasiswa lainya di kampus IAIN Pontianak.

\section{Konsep Pacaran dalam Perspektif Mahasiswa}

Sebagian mahasiswa IAIN Pontianak memahami bahwa pacaran dianggap sebagai hal yang negatif. Berikut ini ialah beberapa pandangan mahasiswa yang mengikuti konsep jomlo mengenai pacaran.

"Pacaran dari segi manapun kurang baik, apalagi jika sampai menghalalkan yang jelas haram. Kalau untuk menikah memang harus mengenal terlebih dahulu batas mengenal biasanya sampai 3 bulan, lebih dari itu biasanya bukan lagi disebut ta'aruf malah bisa di bilang pacaran. Lebih baik pacaran itu setelah menikah meskipun mungkin banyak orang yang masih menganggap aneh."

"Pacaran sebelum menikah itu tidak baik, karena ada pacaran setelah menikah. Dalam hal ini Islam telah mengatur hubungan antar lawan jenis sampai ke jenjang pernikahan dengan memberikan proses ta'aruf nazhar (mengenal), khitbah, dan menikah. Tapi semuanya kembali kepada pribadi masing-masing dalam meniatkan hubungan mereka. Pacaran hari ini berbeda dengan pacaran zaman dulu, pacaran yang ibu dan ayah saya terapkan dulu tidak seperti pacaran yang ada pada hari ini."

"Pacaran itu sebagai sebuah kegiatan yang mengandung nilai yang negatif. Karena hubungan pacaran tidak ada dalam agama dan pacaran penyebab rusaknya norma dan moral remaja."

"Pacaran itu adalah suatu hal yang jelasjelas buang-buang waktu, jika ditanya dari segi baik dan buruknya, jawaban saya jelas pacaran itu buruk."

Terlihat dengan jelas bahwa pergeseran makna pacaran itu terjadi secara merata, bahwa sebagian besar mahasiswa memiliki perspektif yang sama tentang pacaran sebagai sebuah kegiatan yang negatif. Secara umum mereka lebih memilih untuk menikah dan tidak berpacaran sebelum menikah, bahkan pacaran yang Islami sekalipun belum dapat menjamin seseorang untuk tidak berbuat zina. Sebuah penelitian di kota Yogyakarta menunjukkan bahwa sebagian besar remaja melakukan ritual keagamaan hanya karena sebuah keyakinan, belum menjadi kebutuhan psikis dan spiritual (Afiatin 1998). Seharusnya, pemahaman agama 
tidak hanya dipahami sebatas konteks ibadah saja, tetapi juga tentang bagaimana nilai ibadah tersebut dapat diaplikasikan dalam kehidupan sosial, karena perubahan pola pikir yang dapat membentuk kita menjadi orang-orang religius dan juga humanis (Dewi 2012). Sebagian besar, pemahaman spiritual remaja saat ini hanya sebatas pada pelaksanaan kewajiban, belum meresap menjadi akhlak yang melandasi tingkah lakunya. Besar kemungkinan remaja saat ini dengan mudah melakukan hal-hal yang menyimpang, sulit membentengi diri, tahu mana yang baik dan benar, buruk dan salah, namun sulit mengontrol diri untuk menyeimbangkan antara hukum halal haram dengan hasrat dan keinginan.

Sekolah atau perguruan tinggi sebagai lembaga pendidikan juga perlu memperhatikan pemahaman keagamaan peserta didiknya, sehingga tetap mampu berupaya untuk meningkatkan kualitas peserta didik dalam hal sikap dan interaksi antar pelajar, bukan justru memberikan ruang pelanggengan atas nilai-nilai ketidaksetaraan jender yang justru kontraproduktif dengan tujuan pendidikan nasional (Muafiah 2013). Dalam menghadapi fenomena tersebut, konsep diri seseorang menjadi hal penting dalam membentuk tingkah laku seseorang. Setidaknya ada dua konsep diri, yaitu konsep aspek fisik yang berhubungan dengan keadaan tubuh, penampilan individu dan aspek psikologis yang berhubungan dengan harga diri, rasa percaya diri, dan kemampuan dan ketidakmampuan. Peningkatan konsep diri seseorang akan diikuti pula dengan penurunan kenakalan remaja (Yulianto 2014).
Konsep diri seseorang yang rendah, menentukan perilaku seseorang terhadap perilakunya, gaya hidupnya, dan gaya berpacarannya. Sebuah penelitian mengungkapkan tentang gaya berpacaran remaja yang sudah pernah aborsi karena hamil di luar nikah, sudah sampai pada tahap berhubungan seksual (intercourse) padahal sudah pernah merasakan sakitnya diaborsi. Artinya, aborsi tidak menjadikan seseorang jera dengan perilakunya yang jelas-jelas jauh menyimpang dan memberikan akibat yang negatif (Zulfawati, Damayanti, dan Purwanti 2013). Gaya pacaran yang tidak sehat seperti itulah yang dilarang keras oleh Islam, pacaran yang orientasinya bukan lagi untuk saling mengenal satu sama lain, menghindari penyesalan berumah tangga akibat tidak saling mengenal. Pacaran yang diperbolehkan di dalam Islam adalah pacaran yang bertujuan agar memperroleh bahagia dalam hidup berumah tangga dunia dan akhirat (Aziz dan Aminuddin 2014). Sebuah hubungan pacaran dibangun dengan serius, komitmen untuk menikah, menjadi sebagai sebuah orientasi pengenalan antar pasangan sebelum menikah dan bertujuan untuk membentuk keluarga yang sakinah, mawaddah dan rahmah sehingga pacaran yang seperti itulah yang di perbolehkan di dalam Islam karena memiliki tujuan yang baik (Aziz dan Aminuddin 2014).

Pertanyaannya, mungkinkah hari ini berpacaran bisa terlepas dari kegiatan fisik? Dalam hubungan berpacaran selalu diidentikkan dengan kegiatan fisik, sehingga pacaran yang sakral yang sama maknanya dengan ta'aruf menjadi bergeser maknanya, dipandang sebagai 
hal yang negatif. Padahal jika benar memahami untuk apa berpacaran itu, apa tujuan berpacaran, pacaran yang seperti apa yang diperbolehkan dalam Islam, maka mungkin konsep pacaran tidak akan terlecehkan seperti yang terjadi saat ini. Pacaran menjadi kegiatan yang sakral, yang bertujuan baik, dianjurkan untuk setiap pasangan mengenal satu sama lain sebelum menikah. Bayangkan jika generasi muda hari ini sudah paham konsep pacaran, paham orientasi berpacaran, paham bentukbentuk dan batasan-batasan berpacaran yang diperbolehkan Islam, maka kegiatan fisik pra nikah menjadi tidak mudah dilakukan.

Sebuah penelitian menunjukkan bahwa pacaran memiliki pengaruh terhadap motivasi belajar. Pacaran merupakan aktivitas sosial. Peran seorang pacar dapat memicu hasil belajar siswa, namun dari segi fisik sebenarnya mereka belum mampu atau belum siap untuk berpacaran sehingga sering kali terjerumus ke dalam hal-hal yang negatif. Padahal sebenarnya pacaran juga dapat memberikan pengaruh yang positif dan negatif terhadap motivasi belajar siswa (Afriansyah, Khususiyah, dan Krisphianti 2018). Dalam hal ini, pola asuh orang tua juga menentukan pola berpikir dan perilaku remaja. Sebuah penelitian mengungkapkan bahwa orang tua dengan pola asuh yang demokratis cenderung membentuk remaja-remaja yang tidak terjerumus hamil di luar pernikahan. Sebaliknya, orang tua dengan pola asuh permisif atau tidak memberikan pengawasan kepada anaknya memiliki tingkat kehamilan di luar pernikahan yang tinggi pada anaknya (Novanti, Anasari, dan Khosidah 2013).
Memahami dampak positif dan negatif dari konsep pacaran saat ini, dirasa menjadi hal yang amat penting untuk melengkapi pemahaman generasi muda tentang konsep pacaran yang saat ini telah mengalami transformasi. Menjadikan jomlo sebagai prinsip yang berdiri sendiri karena alasan sendiri menjadi sebuah kearifan. Sebagai generasi muda yang memiliki prinsip jomlo sampai halal, sudah seharusnya juga ia memiliki pandangan yang baik tentang menikah. Sesungguhnya prinsip jomlo sampai halal itu orientasinya adalah untuk menikah tanpa melalui proses berpacaran. Sehingga dengan memahami konsep menikah, remaja tidak mudah menyatakan diri tanpa membuat pertimbangan sebelumnya dan berujung pada penyesalan rumah tangga. Sebuah penelitian oleh Utami (2015) mengungkapkan bahwa saat ini sedang marak terjadi pernikahan yang dilakukan di usia muda, yaitu karena dilandasi rasa cinta dan merasa siap menikah, kehamilan pra nikah, desakan orang tua, perjodohan, mengikuti tradisi daerah dan lain sebagainya. Sehingga pernikahan yang seharusnya mendatangkan banyak manfaat justru mendatangkan sejumlah konsekuensi yang harus ditanggung oleh remaja.

\section{Konsep Jomlo sampai Halal dalam Perspektif Mahasiswa}

Sebagian mahasiswa IAIN Pontianak memiliki konsep yang menarik tentang jomlo sampai halal. Mereka adalah para mahasiswa yang mempraktekkan konsep tersebut. Berikut ini ialah beberapa pandangan mereka yang ditemukan dalam penelitian. 
"Jomlo sampai halal adalah jomlo sampai ada yang menghitbah, tidak menjemput jodoh dengan pacaran tetapi dengan ta'aruf."

"Konsep jomlo sampai halal itu adalah sebuah motivasi agar tidak pacaran, agar tetap kuat men-jomlo, tetap lurus niatnya yang awalnya men-jomlo jadi tiba-tiba menikah."

“Menurut saya konsep jomlo sampai halal rasanya baru-baru tren beberapa tahun terakhir, sepengetahuan saya itu diperuntukkan untuk orang-orang yang tidak mau pacaran sampai ketemu jodohnya. Tapi saya tidak tau dan tidak bisa memastikan jomlo sampai halal itu benarbenar dari hati atau tidak, karena yang tau hanya dirinya sendiri dan Allah SWT, bisa saja ia mengatakan bahwa ia jomlo sampai halal sementara ia sedang dekat dengan seseorang lawan jenis namun tanpa status, tapi semuanya tergantung juga dekatnya sebatas mana. Jadi menurut saya jomlo sampai halal itu alangkah baiknya jika benar benar diiringi dengan menjaga hati."

"Jomlo sampai halal itu adalah tidak berpacaran sebelum menikah tujuannya adalah untuk menghindari hal-hal yang mengerikan. Takutnya lama-kelamaan akan terjerumus ke dalam kesesatan atau menuju perzinaan."

"Jomlo sampai halal itu dimana seseorang berprinsip untuk menjaga hati orang lain dengan taat kepada Allah, gak mau ngasi harapan ke anak orang, hingga saat dia menikah, itulah jomlo sampai halal."

Sebagian mahasiswa memahami dengan baik konsep jomlo sampai halal, yang mereka fahami sebagai menanti jodoh tanpa maksiat. Maksiat yang dimaksud dalam hal ini adalah berpacaran. Jadi, mereka meyakini akan menjadi jomlo sampai halal jika tidak menjalani hubungan spesial dengan seseorang yang bukan muhrim, kecuali ta'aruf, karena ta'aruf adalah berkenalan untuk selanjutnya menikah. Sederhananya, demikianlah konsep jomlo sampai halal yang dipahami oleh sebagian mahasiswa IAIN Pontianak. Tidak jarang mereka mengisi kegiatan-kegiatan hariannya selain kuliah, juga dengan mengikuti majelis ta'lim, atau bekerja paruh waktu. Tujuan mereka untuk memperbaiki akhlak, mendekatkan diri kepada Allah, mendalami memahami ajaran agama dan bekerja untuk membantu orang tua dalam membiayai kuliah.

Konsep jomlo sampai halal yang seperti itu, mendorong remaja muslim untuk memahami ajaran agamanya tidak sebatas pada menggugurkan kewajiban beribadah, tetapi lebih jauh, meresap menjadi akhlak. Kematangan remaja dalam berpikir juga menentukan sikap mereka dalam memahami sesuatu sehingga ketika beribadah tidak hanya sekedar ritual untuk menggugurkan kewajiban. Dalam hal ini kematangan emosi pada remaja juga menentukan bagaimana remaja bersikap dengan tepat dan wajar sesuai dengan situasi dan kondisinya. Kematangan emosi pada remaja dipengaruhi oleh kelekatan aman, yaitu keterikatan secara emosional antara orang tua dan anak sebagai dasar perkembangan psikologis (Fajarini dan Khaerani 2014). Konsep jomlo sampai halal dipahami dan diterapkan oleh mahasiswa ini, mendorong mereka untuk mengisi kegiatan harian mereka dengan kegiatan-kegiatan yang positif, seperti dengan mengikuti kajian dari masjid ke masjid, mengikuti komunitas hijrah yang ada di pontianak, bakti sosial, membentuk komunitas pelestarian permainan tradisional anak-anak dan ada yang mengisi kegiatan 
malam mereka dengan menghafalkan al-qur'an dengan komunitas penghafal al-qur'an. Selain itu mereka juga bekerja sebagai guru honorer di sekolah-sekolah negeri maupun swasta, dan di pondok pesantren, adapula yang mengajar les privat. Mereka merasa kegiatan-kegiatan positif mereka lakukan lebih membuat mereka bahagia, berguna bagi orang banyak, dan diridhai oleh Allah.

Namun tidak berarti mereka menunda pernikahan karena alasan bekerja atau menunggu akhlak menjadi baik agar mendapatkan jodoh yang baik pula, karena menunda pernikahan juga ada hukumnya. Lebih baik segerakanlah menikah, usahakan diri menjemput jodoh, jangan larut dalam tujuan hidup untuk sukses berkarir atau bahkan sampai lupa mendahulukan perkara yang sunnah didepan perkara yang mubah. Dalam perspektif hukum Islam, bahwasannya hukum bagi seorang wanita yang bekerja adalah mubah (boleh) bahkan bisa menjadi sunnah atau wajib jika benar-benar dibutuhkan dan dalam keadaan terpaksa harus menikah demi kebutuhan hidup. Namun tetap terikat beberapa syarat, jangan sampai menunda pernikahan lebih banyak memberikan dampak negatif daripada dampak positif, karena mementingkan bekerja yang hukumnya mubah daripada memilih menikah yang hukumnya sunnah adalah bertentangan dengan hukum Islam (Bayali 2013). Sehubungan dengan hal itu, ada sebuah tulisan yang dilatar belakangi oleh kesadaran tentang modernitas yang selalu bergerak tanpa memperdulikan bias negatif dari adanya mordenitas itu, terjadi revolusi dalam cara hidup, per- ubahan itu menyangkut semua bidang dan aspek kehidupan.

Secara material manusia mengalami kemajuan yang spektakuler secara kuantitatif, namun secara kualitatif dan keseluruhan tujuan hidupnya, manusia mengalami krisis yang sangat berat. Megatrens (Hamzah 2015) mengatakan bahwa dalam kondisi seperti ini, maka agama merupakan satu tawaran dalam kegersangan dan kehampaan spiritualitas manusia-manusia modern. Era milenium seperti sekarang merupakan era kebangkitan agama dan nilai-nilai esoteric. Bagi manusia modern, ekses-ekses negatif yang ditimbulkan oleh modernisasi akan mampu diproteksi oleh karifan esoteric sebuah religiusitas. Walaupun agama merupakan sesuatu yang inheren dalam kemanusiaan manusia, tetapi agama tidak dapat serta merta mendarah daging pada diri manusia, agama merupakan sebuah proses, yang harus terus-menerus dipupuk dalam upaya yang sistematis dan terencana, yang terpola dalam dunia pendidikan. Tentu pendidikan agama yang dimaksudkan dalam konteks ini bukan hanya mengajarkan tentang doa dan tata cara beribadah, tetapi lebih luas daripada itu, sebagai upaya untuk menciptakan manusia yang bermoral, beretika dan bermartabat dalam tiap tindakan praktis yang dilakukannya (Hamzah 2015).

\section{Hal-hal yang Memotivasi Mahasiswa Memilih untuk Jomlo}

Setelah melalui proses wawancara, maka didapatlah pernyataan-pernyataan verbal dari responden mengenai hal-hal apa saja yang 
memotivasi mereka untuk memilih jomlo seperti yang dipaparkan berikut ini.

"Mungkin karena hati, lebih enak sendiri dari ada harus ada pasangan yang masih belum jelas, lebih leluasa mau ngapain tanpa ada yang harus tau. Dari segi agama memang pacaran itu tidak boleh dan bahkan diharamkan. Semenjak saya ikut rohis sewaktu SMA dulu, saya semakin paham semakin mengerti dosa-dosa dalam berpacaran dan itu salah satu penguat untuk diri saya tidak berpacaran."

"Keputusan saya untuk tidak pacaran sampai nikah cuma karena Allah, saya takut, saya hanya manusia biasa, saya gak mau nambah dosa dengan hal sesepele pacaran yang 'saya anggap enak'. Tidak. Pacaran itu lebih banyak mudharatnya, maka lebih baik saya tidak."

"Karena saya ragu-ragu, dan saya yakin bahwa lebih aman jika menikah daripada berpacaran."

"Apa yang memotivasi saya untuk tidak berpacaran adalah: 1) seiring dengan menambahnya pengetahuan saya tentang agama, menjadi semakin bertambah kesadaran saya. 2) lingkungan, dalam pergaulan sebenarnya saya tidak pilih-pilih teman, namun bagaimana saya mengambil pelajaran dari teman-teman saya itulah yang menjadikan saya istiqāmah untuk teguh pendirian."

"Hanya ingin memantaskan diri, karena harapan orang tua terhadap kesuksesan anaknya, ingin menggapai kesuksesan baik sukses untuk diri sendiri, dan untuk orang lain, saya tidak mau terkekang dengan banyak aturan, saya ingin mandiri sendiri, dan saya termotivasi untuk men-jomlo karena menganggap kalau pacaran itu perbuatan dosa. Jadi kalau sudah menemu- kan orang yang cocok, lebih baik langsung menikah saja."

Beberapa pernyataan mahasiswa yang dikutip tersebut menunjukkan bahwa secara umum kesadaran dalam beragama menjadi motivasi terbesar bagi mahasiswa dalam berpikir, bertindak dan berperilaku, dalam menentukan prinsip hidup, menentukan tujuan dan arah hidup yang hendak dicapai. Mahasiswa tersebut melihat pada kondisi hidup di tengah-tengah masyarakat dan tanggung jawab atas satu perbuatan. Mahasiswa semakin sadar dan lebih peka terhadap kemungkinan-kemungkinan negatif yang dapat terjadi. Ada hubungan religiusitas seseorang terhadap kesadaran diri. Maksudnya, semakin tinggi tingkat pemahaman seseorang terhadap agamanya (religiusitasnya) maka semakin tinggi pula kesadaran diri yang dimiliki. Penelitian Akbar, Amalia, dan Fitriah (2018) mengungkapkan ada atau tidaknya hubungan antara religiusitas mahasiswa dengan self awareness (kesadaran diri). Berdasarkan analisis data kuantitatif, pada akhir penelitian tersebut didapatkan hasil penelitian yang menunjukkan bahwa ada hubungan antara religiusitas mahasiswa dengan self awareness (kesadaran diri). Dapat diartikan bahwa religiusitas seseorang dapat meningkatkan kesadaran dirinya. Dalam hal ini ada beberapa dimensi religiusitas yang menurut Kendler (dalam Akbar et al. 2018) sangat penting untuk diperhatikan.

Selain itu, religiusitas yang tertanam dalam diri seseorang juga dapat membantu dalam mengendalikan diri dari perbuatan-perbuatan negatif. Sebuah penelitian tantang hubungan 
religiusitas dan kontrol diri dengan perilaku seksual pranikah remaja yang dilakukan oleh Khairunnisa (2013) menjelaskan bahwa terdapat hubungan yang signifikan antara religiusitas dan kontrol diri dengan perilaku seksual pranikah pada remaja. Hal ini berarti semakin tinggi religiusitas yang dimiliki seorang remaja maka semakin rendah perilaku seksual pranikah remaja yang muncul, dan semakin tinggi kontrol diri yang dimiliki remaja maka semakin rendah perilaku seksual pranikah remaja yang muncul. Kontrol diri berfungsi membatasi individu untuk bertingkah laku negatif. Individu yang memiliki pengendalian diri akan terhindar dari berbagai tingkah laku negatif. Sementara religiusitas dapat ditunjukkan dengan aktifitas ibadah keagamaan, menjalankan nilai-nilai agama dan menghindari perilaku-perilaku yang dilarang oleh ajaran agama. Perilaku yang diatur oleh tuntutan agama akan mengarahkan seseorang dalam mengendalikan dirinya. Religiusitas memiliki peranan yang sangat kuat terhadap kehidupan seseorang, sebab di dalamnya telah terkandung berbagai dimensi kehidupan manusia. Dimensi ini diantaranya yaitu dimensi pengamalan yang memuat berbagai hal tentang konsekuensi akibat keyakinan, praktek ritual, pengalaman dan pengetahuannya tentang agama yang dianut seperti kontrol diri. Selain itu, erat kaitannya dengan religiusitas seseorang bahwa agama mempunyai peran penting dalam mengelola stress. Agama juga dapat memberikan individu pengarahan/arahan, dukungan dan harapan (Utami 2012).
Dengan data yang diperoleh dari penelitian ini dapat dinyatakan bahwa tingkat religiusitas yang dimiliki mahasiswa IAIN pontianak yang berstatus jomlo cukup tinggi sehingga dapat mendorong dan memotivasi diri mereka untuk tidak berpacaran di usia remaja. Selain itu, tingkat religiusitas yang mereka miliki juga dapat membentuk padangan mereka, pola pikir mereka terhadap suatu hal negatif yang dapat terjadi sebagai efek dari berpacaran, sehingga mereka lebih baik tidak berpacaran untuk menjaga diri. Selain itu, koping religiusitas juga berperan dalam kondisi ini, di mana mahasiswa yang memilih untuk jomlo tetap merasakan kesejahteraan dalam hidup, tetap merasa bahagia, bahkan bisa jadi mereka merasa lebih bahagia berstatus jomlo daripada berpacaran. Koping religiusitas mendorong mereka untuk menggunakan keyakinannya dalam mengelolah stress, dan mengelolah masalah-masalah dalam hidup. Selain itu kontrol diri dan kesadaran diri (self awareness) juga berperan penting dalam memotivasi mahasiswa menentukan pilihan hidup yang benar.

\section{Hal-hal yang Menjadi Tujuan Mahasiswa Memilih untuk Jomlo}

Tetap istiqāmah dengan prinsip untuk tidak berpacaran mungkin bukanlah hal yang mudah di kalangan mahasiswa, karena di usia-usia tersebut pacaran merupakan hal yang normal, wajar dan menjadi godaan. Lalu selain pemahaman mereka terhadap ajaran agama Islam sebagai sumber motivasi terbesar, ada beberapa hal yang menjadi tujuan mereka untuk 
teguh memegang prinsip jomlo sampai halal, seperti yang disampaikan berikut ini.

“Tujuannya untuk menikah tanpa pacaran."

"Karena saya belum kepikiran untuk menikah, dan saya ragu dengan pacaran, lebih baik men-jomlo daripada berpacaran, sambil menunggu masanya datang, saya kepikiran dengan menikah."

"Tujuan saya untuk memilih jomlo daripada pacaran karena tidak mau menyakiti hati, menyakiti diri sendiri dengan hubungan yang ada pahit manisnya dan belum jelas."

"Saya men-jomlo bertujuan untuk menghindari dosa, saya takut dosa karena pacaran banyak mengundang maksiat, makanya saya lebih memutuskan lebih tidak pacaran dan memilih untuk berpacaran setelah menikah."

"Tujuan saya hanya untuk mencari cinta Allah, dan saya takut dengan dosa-dosa berpacaran. Jadi saya lebih bertujuan untuk menghindari dosa-dosa."

Sebagian besar mahasiswa mengatakan bahwa tujuan mereka tidak berpacaran adalah untuk mencari ridha Allah, takut pada dosadosa yang akan dipertanggung jawabkan. Maka tidak sedikit mahasiswa yang merasa lebih baik menikah daripada berpacaran. Namun, menikah tidak selalu menjadi solusi, jika menikah hanya dilandaskan untuk menghindari maksiat, tanpa adanya komitmen, keseriusan, kematangan dari segi usia, dan kecocokan antar pasangan. Sehingga terlalu sederhana jika seseorang menjadikan menikah sebagai solusi untuk menghidari maksiat berpacaran. Ada banyak hal yang harus dipahami mahasiswa sebelum akhirnya menikah, karena tanpa pertimbangan dan persiapan maka dikhawatirkan terjadi penyesalan dalam membina rumah tangga, tidak tercapai tujuan rumah tangga yang sakinah mawaddah dan rahmah. Kematangan dari segi usia menjadi salah satu faktor yang menentukan tingkat kesiapan seseorang untuk menikah. Menurut Muchlisah (2012), tingkat kemampuan penyesuaian pernikahan pada wanita remaja yang menikah di usia muda lebih rendah dari pada tingkat kemampuan penyesuaian pernikahan pada wanita dewasa. Secara psikologis, seseorang yang usianya tergolong dewasa akan lebih siap secara emosional untuk menikah dibandingkan dengan seseorang yang masih remaja. dalam hal ini psikologi perkembangan juga memiliki pembahasan yang sama, bahwa perubahan individu secara bertahap seiring usianya, yang berarti semakin dewasa maka semakin stabil dan matang mentalnya.

Usia ketika menikah adalah hal penting yang akan mempengaruhi masa depan individu. Jika dikaji lebih dalam kesuksesan dalam pernikahan akan lebih mungkin dicapai ketika usia perempuan \pm 25 tahun dan laki-laki berusia \pm 28 tahun atau dapat dikatakan dewasa dalam tinjauan usia. Dengan kata lain akan lebih mungkin menghasilkan suatu lembaga pernikahan yang sukses bila individu menikah di usia dewasa. Berjalan atau tidaknya sejumlah fungsi keluarga sangat ditentukan oleh kesiapan dan kematangan kedua calon pasangan, kesiapan dan kematangan dalam hal ini berikaitan dengan kematangan pada tingkat kompetensi dan atau tingkat pengetahuan tentang seluk beluk kehidupan rumah tangga, sangat dibutuhkan pengetahuan calon pasangan suami istri agar dapat menjalankan sejumlah fungsi 
keluarga (Nasution 2015). Secara garis besar, ada dua penyebab utama ketidakharmonisan dalam rumah tangga, antara lain adalah karena kekurangan nafkah lahir dan batin. Maka, untuk dapat menghadapi hal ini pada kehidupan rumah tangga, pasangan suami istri harus mendapatkan pembekalan dan pemahaman terkait hak dan kewajiban dalam rumah tangga (Iskandar 2017).

Konseling pra-nikah sebagai salah satu sarana untuk memberikan bantuan kepada individu sebagai pemimpin atau anggota keluarga agar mereka mampu menciptakan dan menyesuaikan diri secara produktif, dapat menciptakan keluarga yang utuh dan harmonis, memberdayakan diri secara produktif, dapat menciptakan dan menyesuaikan diri dengan norma keluarga, serta berperan aktif dalam mencapai kehidupan keluarga bahagia (Mubasyaroh 2016). Dalam hal ini, ada hubungannya antara kepuasan pernikahan dengan tingkat religiusitas yang tinggi pada pasangan suami istri dalam hidup berumah tangga, semakin tinggi tingkat religius suami istri maka mereka akan semakin puas dengan pernikahan mereka, dan sebaliknya semakin rendah tingkat religiusitas suami istri maka mereka akan merasa kurang puas dengan pernikahannya, selain itu usia perkawinan, jenjang pendidikan, tradisi sosial budaya juga mempengaruhi tingkat kepuasan pernikahan seseorang (Istiqāmah dan Mukhlis 2015). Lebih lanjut, ada sebuah penelitian yang mengungkapkan adanya hubungan antara religiusitas dan kebahagiaan seseorang, semakin tinggi religiusitas seseorang semakin ia mengalami kesejahteraan psikologis. Dalam hal ini kesejahteraan psikologis dikenal dengan istilah psycological well being, atau kesejahteraan yang menekankan kebahagiaan terhadap adanya hidup yang bermakna. Seseorang dikatakan bahagia dan sejahtera apabila mengisi hidupnya dengan hal-hal yang bermakna, yang bertujuan, yang berguna bagi kesejahteraan orang lain, dan pertumbuhan dirinya sendiri (Mayasari 2014).

\section{Kesimpulan}

Pacaran telah menjadi fenomena yang terjadi sejak lama dan nejadi bagian dari kehidupan manusia. Namun sesuai perkembanganya, pacaran telah direspon dengan berbagai sikap oleh manusia. Berdasarkan analisis data, dapat disimpulkan bahwa di kalangan mahasiswa IAIN Pontianak yang melakukan konsep jomlo, pacaran dianggap sebagai sebuah kegiatan yang negatif, dan oleh karena itu mereka lebih memilih untuk menikah dan tidak berpacaran sebelum menikah. Bahkan mereka menolak apa yang disebut sebagai pacaran yang Islami sekalipun, karena mereka meyakini bahwa pacaran tersebut tidak dapat menjamin seseorang untuk tidak berbuat zina. Dengan demikian maka konsep pacaran mengalami transformasi, karena pacaran memiliki pengaruh yang positif dan negatif. Pemahaman atas kedua sisi itu dapat memperkaya pengetahuan mahasiswa tentang pentingnya berkenalan sebelum menikah dan lebih mempertimbangkan untuk menikah di usia muda tanpa melalui proses perkenalan yaitu proses ta'aruf atau pacaran.

Selanjutnya, beberapa memotivasi mahasiswa memilih untuk jomblo meliputi kesadaran dalam beragama yang menjadi motivasi terbesar 
mahasiswa dalam berpikir, bertindak dan berperilaku, dalam menentukan prinsip hidup, menentukan tujuan dan arah hidup yang hendak dicapai. Mahasiswa semakin sadar dan lebih peka terhadap kemungkinan-kemungkinan negatif yang dapat terjadi dari kegiatan berpacaran, sehingga memotivasi mereka untuk lebih memilih tidak berpacaran. Mereka mengangap bahwa kegiatan berpacaran lebih banyak mendatangkan dosa, maka lebih baik mereka melakukan kegiatan-kegiatan yang dapat mendatangkan pahala seperti dengan bergabung dengan komunitas-komunitas hijrah, mengikuti kajian-kajian keagamaan, membatasi diri dalam bergaul, dan cenderung akrab dengan temanteman kelas yang memiliki pandangan yang sama tentang dampak negatif berpacaran. Selain itu, berkumpul dengan teman-teman yang sama sama memilih untuk tidak berpacaran juga menjadi salah satu motivasi mahasiswa untuk juga tidak berpacaran.]

\section{Daftar Pustaka}

Afiatin, Tina. 1998. "Religiusitas Remaja: Studi tentang Kehidupan Beragama di Daerah Istimewa Yogyakarta." Jurnal Psikologi 25(1):55-64.

Afriansyah, Alik Bima, Khususiyah Khususiyah, dan Yuanita Dwi Krisphianti. 2018. "Pengaruh Aktifitas Pacaran terhadap Motivasi Belajar pada Siswa Kelas XI SMK Pemuda Papar." Nusantara of Research 5(1):29-32.

Akbar, M. Yudi Ali, Rizqi Maulida Amalia, dan Izzatul Fitriah. 2018. "Hubungan Relijiusitas dengan Self Awareness Mahasiswa Program Studi Bimbingan Penyuluhan
Islam (Konseling) UAI." Jurnal Al-Azhar Indonesia 4(4):265-70.

Ardhianita, Iis dan Budi Andayani. 2005. "Kepuasan pernikahan ditinjau dari berpacaran dan tidak berpacaran." Jurnal Psikologi 32(2):101-11.

Aziz, Abdul dan Faiz Aminuddin. 2014. “Ta’aruf di Kalangan Remaja dalam Tinjauan Psikologi Hukum Islam." Jurnal Islamic Review (JIE) 3(2):387-411.

Bayali, Cip. 2013. "Menunda Pernikahan bagi Wanita Karir Menurut Hukum Islam." Hukum Islam 13(1):84-96.

Dewi, Ernita. 2012. "Transformasi Sosial dan Nilai Agama." Substantia: Jurnal Ilmu-ilmu Ushuluddin dan Filsafat 14(1):112-21.

Faiza, Arum. 2018. Bila Cinta Bermula dan Berakhir pada Allah maka Cinta yang Lain Hanya Cermin Cinta kepada-Nya. Yogyakarta: Noktah.

Fajarini, Febri dan Nuristighfari Masri Khaerani. 2014. "Kelekatan Aman, Religiusitas, dan Kematangan Emosi pada Remaja." Jurnal Psikologi Integratif2(1):22-29.

Firmiana, Masni Erika, Meithya Rose Prasetya, dan Rochimah Imawati. 2014. "Ketimpangan Relijiusitas dengan Perilaku: Hubungan Religiusitas dengan Perilaku Seksual Pra Nikah Remaja SMA/Sederajat di Jakarta Selatan." Jurnal Al-Azhar Indonesia 1(4):239-45.

Hamzah, Nur. 2015. "Pendidikan Agama dalam Keluarga." At-Turats: Jurnal Pemikiran Pendidikan Islam 9(2):49-55.

Iskandar, Zakyyah. 2017. "Peran Kursus Pra Nikah dalam Mempersiapkan Pasangan Suami-Istri Menuju Keluarga Sakinah." AlAhwal: Jurnal Hukum Keluarga Islam 10(1):85-98. 
Istiqomah, Imannatul dan Mukhlis Mukhlis. 2015. "Hubungan Antara Religiusitas dengan Kepuasan Perkawinan.” Jurnal Psikologi 11(2):71-78.

Khairunnisa, Ayu. 2013. "Hubungan Antara Religiusitas dan Kontrol Diri dengan Perilaku Seksual Pranikah Remaja di MAN 1 Samarinda." Psikoborneo: Jurnal Ilmiah Psikologi 1(2):220-29.

Koentjaraningrat. 2009. Pengantar Antropologi Pokok-Pokok Etnografi. Jakarta: Rineka Cipta.

Maslahah, Ani Agustiyani. 2013. "Pentingnya Kecerdasan Spiritual dalam Menangani Perilaku Menyimpang." Konseling Religi: Jurnal Bimbingan Konseling Islam 4(1):2134.

Mayasari, Ros. 2014. "Religiusitas Islam dan Kebahagiaan (Sebuah Telaah dengan Perspektif Psikologi)." Al-Munzir 7(2):81100.

Muafiah, Evi. 2013. "Investigasi Empiris Atas Prestasi Belajar Siswi Madrasah Aliyah Model Single Sex Education dan CoEducation di Kabupaten Ponorogo." Kodifikasia: Jurnal Penelitian Islam 7(1):1-16.

Mubasyaroh, Mubasyaroh. 2016. "Konseling Pra Nikah dalam Mewujudkan Keluagra Bahagia (Studi Pendekatan Humanistik Carl R. Rogers)." Konseling Religi: Jurnal Bimbingan Konseling Islam 7(2):1-18.

Muchlisah, Muchlisah. 2012. "Perbedaan Usia Wanita Ketika Menikah (Remaja dan Dewasa) dalam Hubungannya dengan Penyesuaian Pernikahan di Kota Makassar." Jurnal Psikologi 8(2):105-10.

Nasution, K. 2015. "Peran Kursus Nikah Membangun Keluarga Sejahtera." Jurnal Ahkam 15(2):181-88.
Novanti, Nia, Tri Anasari, dan Amik Khosidah. 2013. "Hubungan Pola Asuh Orangtua dengan Kejadian Kehamilan di luar Nikah pada Remaja di Kecamatan Randudongkal Tahun 2013." Jurnal Kebidanan 2(2):5055.

Nugraha, Tisna. 2015. "Revitalisasi Pendidikan Akhlak Mulia dalam Pembentukan Karakter Mahasiswa di Perguruan Tinggi Agama Islam." Raheema: Jurnal Studi Gender dan Anak 2(2).

Panaemalae, Abdul Razak Abdulroya dan Zaenuddin Hudi Prasojo. 2016. "Islam and the West: Tariq Ramadan and the Discourse of Religion of Peace for a Global Understanding." Al-Albab 5(2):237-50.

Pujiati, Sri, Edy Soesanto, dan Dwi Wahyuni. 2013. “Gambaran Perilaku Pacaran Remaja di Pondok Pesantren Putri K.H Sahlan Rosjidi (Unimus) Semarang." Jurnal Kebidanan 2(2):13-21.

Setiawan, Rony dan Siti Nurhidayah. 2008. "Pengaruh Pacaran terhadap Perilaku Seks Pranikah." Soul: Jurnal Ilmiah Psikologi 1(2):59-72.

Su'dadah, Su'dadah. 2014. “Kedudukan dan Tujuan Pendidikan Agama Islam di Sekolah." Jurnal Kependidikan 2(2):14362.

Sutrisno, Mudji dan Hendar Putranto. 2005. Teori-teori Kebudayaan. Yogyakarta: Kanisius.

Syarif, Muhajir. 2014. "Pendidikan Agama Islam dalam Pembentukan Karakter Bangsa (Studi Analisis Perilaku Siswa Madrasah Aliyah Negeri 1 Palembang)." Conciencia 14(2):71-93. 
Utami, Fajar Tri. 2015. "Penyesuaian Diri Remaja Putri yang Menikah Muda." Psikis: Jurnal Psikologi Islami 1(1):11-21.

Utami, Muhana Sofiati. 2012. "Religiusitas, Koping Religius, dan Kesejahteraan Subjektif." Jurnal Psikologi 39(1):46-66.

Yulianto, Dema. 2014. "Hubungan Antara Konsep Diri dan Kecerdasan Emosi dengan Ke- nakalan Remaja." Nusantara of Research 1(1):76-82.

Zulfawati, Restia, Fitriani Nur Damayanti, dan Indri Astuti Purwanti. 2013. "Studi Kualitatif tentang Perilaku Pacaran Siswi SMA Pasca Tindakan Aborsi di Kecamatan Belik." Jurnal Kebidanan 2(2):93-97. 